\title{
Antagonistic threats against supply chain activities are wicked problems
}

\author{
Daniel Ekwall
}

Received: 6 January 2012 / Accepted: 16 January 2012

(C) Springer Science+Business Media, LLC 2012

\begin{abstract}
The purpose of this paper is to analysis and present that antagonistic threats against supply chain activities are wicked problems. The research is based on a system-theoretical approach, which emphasizes a holistic view instead of the characteristics of the different parts. The research method used in this paper is deductive desk research. This research is mainly theoretical, and the findings are contributions to the development of theoretical models and understanding in order to further move the scientific understanding about antagonistic threats against supply chain activities. The main reason behind this is the relationship between threats and countermeasures that are complex and contextual depended. There are several types of crime that can be linked to the logistics function and processes. This paper does not address the problems from a legal viewpoint. This paper presented descriptions of four different antagonistic threats, namely theft, terrorism, smuggling and piracy. The nature of these four different antagonistic threats is then analyzed with regards to the wicked problem description, which leads to the conclusion that antagonistic threats are better described as wicked problems.
\end{abstract}

Keywords Antagonistic threats · Wicked problem - Supply chain · Terrorism · Piracy · Cargo theft

\section{Introduction}

The World Trade Centre attack in 2001 changed the world and with it the conditions for logistics worldwide (Sheffi 2001: Burke 2005). The aftermath of the attack brought needed attention to the vulnerability of modern supply chains. This vulnerability can in many cases be described as "unwanted effects" in the supply chain caused either by internal or external forces that create disturbances larger than the

D. Ekwall $(\bowtie)$

School of Engineering, Borås, Sweden

e-mail: Daniel.Ekwall@hb.se 
supply chain is designed to handle. The disturbance can be either unintentional or deliberate and legal or illegal. Antagonistic threats are a special and limited array of risks and uncertainties that are demarcated by three key words: deliberate (caused), illegal (defined by law), and hostile (negative impact, in this thesis, for transport network activities). According to Ekwall (2009a) is: Antagonistic threats are deliberately caused illegal and hostile threats against the planned or wanted logistics process, function, and structure. Based on this definition, the core element for antagonistic threats are motivated perpetrators with hostile intentions toward the object and/or third party that violate an international, country, or local law. The antagonistic threat is therefore a crime and can be understood with the use of theories from criminology, or the scientific study of crime in combination with, in this paper, logistics theories. This leads to that this paper uses an interdisciplinary exchange of views, ideas, and theories which is needed to develop as an applied science (Klaus et al. 1993; Stock 1997).

\section{Purpose of this paper}

The purpose of this paper is to analyse if antagonistic threats against supply chain activities can be describe as wicked problems. This is done against a background of the believed increasing threats from both economically driven and non-economically driven crimes which all calls for higher or better security.

\section{Method}

The research method used in this paper is deck top deductive. The research in this paper follows the tradition in logistics of using a system approach to answer research questions (Aastrup and Halldórsson 2008; Hellström 2007; Gammelgaard 2004). Checkland (1999) describes the concept of system as: "The central concept 'system, embodies the idea of a set of elements connected together which form a whole, this showing property which are properties of the whole, rather than properties of its components". The main idea of system theory is to illuminate holistic thinking; it is based on the assumption that a whole system is different from the sum of its components (Churchman 1968; Hellström 2007). This paper uses a hard system approach (Checkland 1999) which implies both an objective reality and a top-down perspective on the system in order to how the different elements interact with each other (Hellström 2007). The wicked problem labelling of antagonistic threats is possible by using a system approach, especially when it comes the interaction between stakeholders and antagonistic threat prevention.

\section{Interdisciplinary research mixing criminology into logistics}

According to several authors (Stock 1997; Arlbjörn and Halldorsson 2002; Solem 2003), criminology is interdisciplinary research of the history and future of crimes, and this paper follows this tradition by using theories from criminology to strengthen 
the field of logistics. This mix of theories also challenges the predominant research approach in logistics related to tangible artefacts (Gubi et al. 2003), and human intervention or influence to a smaller extent (Aastrup and Halldórsson 2008). The reason for this approach is that violation of law is considered a human attribute. Criminology distinguishes three elements of a crime that are present in all sorts of crime ranging from occasional violence to advance and complex economic crimes (Sarnecki 2003; Sherman et al. 1989; Sampson et al. 2010). The elements are:

1. Motivated perpetrator

2. Suitable object

3. Lack of capable guardian

These three different elements can be described as:

Motivated perpetrator: The perpetrator is an individual that, based on the outcome of the own decision process, commits a certain action or prepares for a certain action that is prohibited by locality or country of international law. The perpetrator can be modelled with two different categories depending on how decisions are made by each individual, namely rational choice theory (also known as the economical man theory) or determinism (Sarnecki 2003; cf Mankiw 1997). It is commonly agreed that different crimes demand various mixtures of rational choice and determinism from the perpetrator's side, where crimes of passion (sexual crime, etc.) are considered more deterministic than property crimes (economic crime, etc.), which are more rational (Bodman and Maultby 1997). Thus, therefore can the general description of human behaviour be described as acting rational on the margin or limited (by circumstance, choice or mixture of both) rational choice (Simon 1982; Gigerenzer and Reinhard 2002).

Object: The desirable outcomes or objects for the motivated perpetrator differ greatly depending on the motivated perpetrator's decision process. Normally is it suitable to describe the object as the primary or direct reason for the action, but also as secondary or indirect reasons (cf Sampson et al. 2010). The primary objects can be shipped products, resources used, infrastructure, or even the media attention an attack will receive (terrorist attacks, action junkies etc.). It is in the relationship between object and motivated perpetrator that the categorisation of the antagonistic threat is found (Ekwall 2009a).

Lack of capable guardian: The preventive measures that can be induced to alter the motivated perpetrator's decision process are called security (Manunta 1999). If the security measures are considered insufficient by the motivated perpetrator, then there is nothing to prevent the crime (Sampson et al. 2010).

Most important to remember about the elements of crime is that it is first when all three elements comes together at the same time that a crime is possible. This means that if one of the three elements is missing than is crime impossible. Any combination of lack of security and target are normally referred to as a crime opportunity. According to Clarke and Cornish (2003) are both a motivated perpetrator and a crime opportunity needed in order for a crime to occur. The theory of crime opportunity also refers to the fourth principle of microeconomics (Mankiw 1997) - people respond to 
incentives - and there the degree of necessary opportunity or incentive depends on the individual. The incentives could range from vindication to morality, ethics, altruism, or determinism (Ekwall 2009a; Kroneberg et al. 2010). Altogether, this leads to that the relationship between threats (motivated perpetrator) and countermeasures (security) linked around a desirable outcome or object, are complex and contextual depended.

\section{Frame of reference}

Supply chain activities, logistics and transport

Christopher (2005) defines the supply chain as, "The network of organisations that are involved through upstream and downstream relationships in the different processes and activities that produce value in the form of products and services in the hands of the ultimate customer". These processes can be in different companies or in the same company. According to Lambert et al. (1998a) can SCM be separated into three elements namely: network structure, business processes and management components. The network structure concerns organisational and geographical relationships. The business processes represents the activities in the supply chain and the management components integrates the network structure with different business processes. The different building blocks in a supply chain can, literally, be located throughout the world and connected through the use of a transport network. The scope of logistics pertains to all activities from the supplier to the customer to provide the right product, at the right time and the right place (Christopher 2005). To be successful, all aspects of operations and information need to work together. The supply chain is a network of autonomous or semi-autonomous business processes that produce physical goods or services to customers (Lin and Shaw 1998). The transport network is designed to use economy of scale when moving products from consignor to consignee in a supply chain, through nodes and links. This means the transport network only physically integrates the supply chain with the fulfilment of its transport demands (Bowersox et al. 2002).

\section{Wicked problem}

Logistics problems are typically classified as tame problems (Conklin 2001), recognized as (Ritchey 2008):

- has a relatively well-defined and stable problem statement.

- has a definite stopping point, i.e., we know when a solution is reached.

- has a solution which can be objectively evaluated as right or wrong.

- belongs to a class of similar problems which can be solved in a similar manner.

- has solutions which can be tried and abandoned.

Normal logistics issues such as efficiency in production or cost efficient distribution setup are easily associated as tame problems according to Ritchey's classification (2008). However, antagonistic threats against supply chain activities do not fit the description of a tame problem. The opposite of a tame problem is a wicked problem, which Ritchey (2008) defines as ill-defined, ambiguous, and associated with strong 
moral, political, and professional issues. Also, these problems are strongly stakeholder dependent and the description of the problem constantly changes because it consists of a vast range of complex and interacting components evolving in a dynamic context.

According to several authors (Rittel and Webber 1973; Ackoff 1974; Rosenhead 1996; Navarro et al. 2008; Mainelli 2008; Ritchey 2008; Ekwall 2009a; Tatham and Houghton 2011; Wexler 2009) the term "wicked problem" is applicable if the problem is applied to issues or challenges that cannot be solved through traditional linear and analytical methods. Wicked problems tend to be difficult to define and lack a clear endpoint. A wicked problem depends on stakeholder judgments and interpretation. According to Rittel and Webber (1973), a wicked problem is unique because there are no solution principles that can be drawn from other wicked problems. Rosenhead (1996) suggested the following criteria for wicked problems:

1. Accommodate multiple alternative perspectives;

2. Function through group interaction and iteration;

3. Generate ownership through transparency;

4. Facilitate a representation of the solution space;

5. Focus on relationships between alternatives rather than continuous variables; and

6. Concentrate on possibility rather that probability.

The nature of a wicked problem is best described as "any solution, after being implemented, will generate waves of consequences over an extended - virtually an unbounded - period of time. The next day's consequences of the solution may yield utterly undesirable repercussion" (Rittel and Webber 1973). The statement clearly demonstrates that a wicked problem has multiple stakeholders, competing interests, multiple fairly incompatible goals, and no universal solution (Wexler 2009).

Crimes and human driving forces for crimes

According to Landes (1998), all human driven forces (the core of the human motivation and salvation) can be simplified through God, gold, and glory. They all play a role in human activities, but the strongest is gold because it pays the bills, equips organisations, tempts, and soothes human flesh (Landes 1998; cf. Smith 1776; Mankiw 1997). This general description of human driving forces is simplistically reformulated into two basic types of antagonistic threats to supply chain activities economically driven and non-economically driven crimes. This classification may seem too simple at first, but in reality tends to be valid more or less for all crimes, even against supply chain activities. Therefore, the classification refers to the primary reason/motivation behind the perpetrator's actions. The commonly most known economically driven crimes are robbery, theft, burglary, pilfering, and smuggling goods or humans. There also are a number of other economically driven crimes that could occur together with antagonistic threats such as fraud, corruption, tax evasion, and money laundering (Pashev 2007; Ksenia 2008; Ross and Hannan 2007; Chong 2003). The theft problem is aimed directly toward the logistics activities while the smuggling abuses the supply chain for illegal purposes. Noneconomically driven crimes include terrorism, sabotage, and different types of violence (Naylor 2004; Burnett 2002; Findlay 1999; Napoleoni 2004; Larmour and Wolanin 2001; Clutterbuck 1987). The primary reason/motivation behind the actions 
are based on political, ideological, or religious ideas or other non-economical philosophical ideas or teaching. Terrorism is defined by TE-SAT (Europol 2007) as, "not an ideology or movement, but a tactic or a method for attaining political goals. Altogether these crimes can be referred to as antagonistic threats. Mutual for all these different types of crimes are that they occur in the surrounding to supply chain activities and different types of security initiatives are needed in order to prevent negative effects on supply chain performance.

According to Smith (1776), human motives often can be described as driven by selfishness and greed. A perpetrator's decision process can be described using five areas or components (Beck 2002): temptation, motivation, opportunity, risk, and consequences. Each factor can have a negative or positive effect on the risk of crime and they can work in isolation or in combination depending upon the circumstances (Beck 2002). The two sides (negative or positive effect) of each component are the key understanding of Smith's belief (1776) that regardless of the motives, society as a whole can benefit if the different motives are exposed to the forces of a free market. The five different areas or components of a perpetrator's decision process can be described as the following (Beck 2002):

Temptation is primary triggered by the perpetrator's greed or need (even perceived need) (Beck 2002). In a store, temptation is used to market a product, but during transport it is not. In stores, the staff handles large amounts of cash which is a possible means of temptation to the individual employee.

Motivation is an important factor in affecting the likelihood to offend. There are three parts which need to be considered: acceptability, neutralisation (or excuses), and marginalisation (Beck 2002). Acceptability means what is accepted in the organisation and what is not. In this part of an offender's motivation is the management's model and actions which show which behaviour is acceptable. Neutralisation is used by offenders when the theft of money or goods is considered to be victimless and nobody really suffers. The third part of the motivation is marginalisation, which explains why some in the staff becomes dishonest. In general terms this can be described as the less the offender has to lose, the greater the risk for dishonest behaviour (Beck 2002). Simply expressed, each individual's morality can be used as a barrier against motivation for criminal acts as well as other legal but unwanted actions.

Opportunity is of critical importance and is based upon three significant factors: space, time, and position (Beck 2002). Space refers to the place (where) for the opportunity while the time factor addresses when. The position factor refers to the work descriptions or tasks that provide crime opportunities.

Risks and consequences are the concern about the risk for discovery and the consequence of the crime. If the perpetrator perceived the likelihood of being caught as low or if the punishment is perceived as soft, then this may encourage theft.

The usage of these factors is based on the rational choice perspective of the perpetrator, or at least a bounded rationality (Ekwall 2009a). These five components of a perpetrator's decision process can be summarised by the central principle in 
microeconomics that all households and firms optimize - "They do the best they can given their objectives and the constraints they face" (Mankiw 1992). The optimize principle is a risk assessment process based on the bounded rationality of the parties involved to optimize their gain (profit/benefit)/trouble (cost/risk) equation from their point of view. The terms profit and cost are not used because the general principle only applies to economically driven perpetrators; bounded rationality can be expressed with profit/benefit and cost/risk, but profit or cost/risk may not be possible to render in monetary terms, rather in perpetrator value terms (Ekwall 2009a; Kroneberg et al. 2010). Altogether, can the different perpetrator's decision process working according variable rationality. This means that different attributes, both on individual and situational interaction level, interact differently according more or less thoughtfully reflective decision making (Heiner 1983). According Kroneberg et al. (2010) do actors often "stick to a particular action alternative in an automaticspontaneous mode of decision making, which leaves aside other alternatives and incentives". This leads to that criminal behavior both can be easy to predict (repeating earlier behavior regardless of incentives or security efforts) and at the same time very dynamic due to the bounded rationality at the perpetrator. In terms of wickedness does this mean that some threats against supply chain activities are full wicked problems, whiles some are more like tame problems. The difference can be found in both the frequency of the problem and also in the dynamic adaptation at the threat side to different preventive measures.

This simplification of antagonistic threat characteristics should be seen as more of a grey-scale than a true classification. Some perpetrators are after the thrill and excitement the accomplishment of the crime will give them. These perpetrators are referred to normally as action junkies, and the action part is a non-economically driven motivation for the crime. The action junky perpetrator may very well be (primarily) after the money or products, but gets adrenalin rush during the realization. A similar type of perpetrator is the attention seeker. At first, attention seekers appear as terrorists. However, they do not seek attention for political, ideological, or religious ideas, but rather for themselves. The driving force is similar to the action junky but instead of getting the rush during the crime these perpetrators get it afterward when they see themselves in the newspapers or on TV. Better security attracts the action junky and the attention seeker, instead of discouraging them from the potential crime (Ekwall 2009a). Several authors (Anderson 2007; Badolato 2000; Tarnef 2006) claim that the sentences for cargo crimes are too soft and that increasing punishment will deter potential perpetrators. In the context of the two outlooks on mankind in criminology, Anderson (2007), Badolato (2000), and Tarnef (2006), state the threats against logistics activities is simply based on the rational choice theory, while authors in criminology (Clarke and Cornish 2003; Felson and Clarke 1998; Horney and Marshall 1992; Klemke 1992; Lab 2000; Sarnecki 2003; Speed 2003) refer to an individual acting rationally on the margin which eliminates the deterring effect of potential punishment that Anderson (2007), Badolato (2000) and Tarnef (2006) suggest. The deterrent effect that a punishment can have on a perpetrator not to commit a certain crime is very low, due to that the perpetrators do not plan to get captured. Therefore has the risk for detection a bigger deterrent effect that the potential punishment (Ekwall 2009a). 
Special cases of Antagonistic threats against supply chain activities

\section{Smuggling of goods}

The primary target of illegal goods is the black market. The black market consists of places and situations where products with doubtful or no legality are traded for money. This market is subject to the same forces of supply and demand as legal ones (FIA 2001). Buyers of these illegal products are everywhere (Johns and Hayes 2003). Statistical reports show that counterfeited and pirated items amounted to $\$ 176$ billion in Europe in 2007 (Rodwell et al. 2007). According to another report from the European Commission, in 2006, nearly 3 million pharmaceutical products were found to be counterfeit (EU Commission 2008). Product smuggling does not necessarily mean that the product is illegal everywhere. What is legal in one country can be illegal in another, which creates the possibility that the actors in smuggling can be legal companies that are trying to access a market that is prohibited for them. An example of this is Western companies that smuggled products into former communist countries during the Cold War era.

A problem linked to smuggling is the manufacturing of products without intellectual rights, or the production of counterfeited goods. Everything that has been produced can be reproduced by someone else. In terms of contraband this simply means that everything can be a counterfeited product (IACC 2005). In order to bring counterfeited products from the production site to the end user, they may have to cross several national boundaries as well as intellectual property legislation. The counterfeiting business evolves constantly within current trends and technologies (Shultz and Saporito 1996). The production and distribution of illegal products is performed under the risk for detection and this diversity leads to a different design of the supply chain. The location of the production facilities is subject to the risk of discovery. Normally, illegal production units are placed where the risk for detection is low, in line with the normal legal business problem of where to produce according to different types of costs and quality aspects. Then, the illegal products are distributed by trade routes and port activities in the same way as legal products (Naylor 2004). The pollution of illegal products in the legal transport network is a serious problem. The most common countermeasure against smuggling is the inspection of cargo carriers when they cross a national border. The mere existence of these inspections creates disturbances in the transport network, even if no illegal product is discovered (Fletcher 2007). The current strategy is to prevent illegal products from entering the transport network by creating secure trade lines (Gutiérrez et al. 2007). The idea of secure trade lines is evident in supply chain security programmes such as AEO, CTPAT, etc. This strategy also aims to reduce the custom inspection disturbances in legal business. For legal businesses, the AEO, C-TPAT, etc., are both a global supply chain headache and a business opportunity, depending on the risk for theft and counterfeiting for that company (Holmes 2004). One common denominator is the use of information to detect illegal products inside legal logistics and flows of purely illegal products.

Naturally, the legal business companies are not pleased with the competition from illegal actors. The striving for better business deals and the general globalization trend that started centuries ago led to an embedding of illegal actions within legal markets 
(Naylor 2004). This implies that the old black markets have been integrated with legal transactions and the markets today can be described as containing every shade of gray when referring to the legality of the markets as a whole (Naylor 2004).

Smuggling is a complex and multi featured problem. The problem linked to counterfeited products really demonstrates that if fulfils the description as a wicked problem. The pure complexity in both crime setup and countermeasures qualify smuggling as wicked problem. What is smuggled and where to, are contextual depended as end market demand and ability to pay (Johns and Hayes 2003) as well as the risk for detection (Ekwall 2009c), from smugglers point-of-view, are major inputs to the perpetrators decision process.

\section{Terrorism}

The word "terror" is a Latin word meaning "to frighten." Consequently, a terrorist is a person that intends to frighten others through fear. The term terrorist/terrorism is itself controversial because its key signature is political and it has been used by states to illegitimatize political opponents. This leads to a vindication of the state's own use of terror against its opponents (Napoleoni 2004). The lack of a universal definition of terrorism is one of the major obstacles for meaningful international countermeasures. The practical consequence of this is best explained with the cynical comment "that one state's terrorist is another state's freedom fighter" (Burns and Peterson 2005). This duality or grey scale definition of the terrorism clearly qualifies terrorism issues as wicked problems.

The World Trade Centre terror attack in 2001 changed the world and the conditions for logistics worldwide. The aftermath of the terrorist attacks clearly indicated that logistics operations will suffer consequences of an attack. The logistics consequences according to Sheffi (2001) were, "It is instructive to note that these disruptions were not caused by the attack itself, but rather by the government's response to the attack: closing borders, shutting down air traffic and evacuating buildings throughout the country Therefore, the antagonistic threat from terrorism can cause consequences indirectly for logistics operations, which economically driven antagonistic threats are less likely to involve. With this said, antagonistic threats in the form of terrorism will also indirectly affect the financial market (Johnston and Nedelescu 2006; Lowe 2006). The effects from attacks will fluctuate depending on factors such as the nature of the attacks, the multiplier effects, the type of policies adopted in response to the attacks, and the resilience of the markets (Bruck and Wickstrom 2004).

The motivation for the majority of terrorist attacks is because the perpetrator intends to influence and alter the current balance of power in a certain direction (Rystad 2006). Both the current balance of power and the potential effects on it may only be understood within the perpetrator's own mind. Therefore, the noneconomically driven antagonistic threat is more nuanced, uncertain, and harder to predict that other types of antagonistic threats. According to Sjöberg (2008) the fear for terrorist attacks is an extreme form of perceived risk. The definition of terrorism influences the difficulty to present valid statistics for the category, because one source may classify an incident as a terrorist act while another considers it to be a "regular" crime. According Europol (2010) is the official reported number of terrorism attack in 
EU declining (581 attacks in 2007 and 294 attacks in 2009) and the major threat (in numbers) comes for separatist movements (Basque and Corsican) whiles Islamist terrorism is still perceived as the biggest threat.

The modern or new thing with terrorism is not the use of violence to influence and alter the current balance of power in a certain direction. This has always been the goal with terrorism. According to Gearson (2002) is: "Terrorism in all its forms, by its very nature, an asymmetrical response to superior force, and terrorist have always used their capabilities as force multipliers - usually through the exploitation of terror. The generation of fear, in effect the use of purposeful violence as a form of psychological warfare can now be carried much further, enhanced by the modern media and the proliferation of mass media as much as by the proliferation of weapons". The new thing with terrorism is therefore more related to development in media technologies than to vulnerabilities in supply chains. Nevertheless, terrorism is a special form of antagonistic threat that needs to be managed, in one way or another.

Terrorism is clearly a wicked problem. A simple review of the history of terrorism provides all needed evidence that terrorism shall be classified as a wicked problem. The official statistics for terrorist attacks indicates that, in order to understand terrorists, if is better to focus on possible attacks instead of probability for attacks. In accordance with this, there are no objective (cf Burns and Peterson 2005) way be determine who is a terrorism and who is not. If there would, terrorism would be a tame problem. This follows the same logic when terrorism is presented as black swan problem (Aggarwal and Bohinc 2011).

\section{Piracy}

The history of piracy clearly signal the wickedness of the problems as stats has earlier been involved is this type of activities by the use of "letters of marquee" which authorized the pirate to attack the ships of the state enemy and share the benefit with the government (Cooperstein 2009). Similar type of action has been done by privateer, buccaneers and corsairs. The modern types of pirates do not act officially of any specific courtiers' order but research has indicated relationship between piracy and weakness of central governances (Jannati and Salimi 2011). In essence is piracy an international crime against all states and the perpetrators can be brought to justice in all everywhere (Abeyratne 2010).

In recent years has the threat from piracy against sea shipment (direct threat) and also against the different supply chains utilizing sea shipment (indirect threat) received increasing attention (Sullivan 2010; Abeyratne 2010; Onuoha 2009; Madden 2009). The real increasing threat from pirates, primary at the horn of Africa (Sullivan 2010; Onuoha 2009), has resulted into both a changes in shipping routes (Sullivan 2010) and also a naval response from several countries (Onuoha 2009) that are depended on a smooth passage of cargo carrying ships. According statistics from IMO, was there 489 attacks last year (2010) and over a twelve year period was there about 347 attacks/year globally (Jannati and Salimi 2011). The trend is currently increasing in number of attacks but also in the modus operandi to more violent ones.

Piracy is a wicked problem as the complexity of the problem is high. The political involvement into the solution mix (due to it is an international crime and that piracy affects global supply chains) leads to that there are no right or wrong solution but 
there are a solution space in which different actions can be taken. The creation of a US Naval Central Command set up a Maritime Security Patrol Area (MSPA) in August 2008 (Onuoha 2009), is clear evidence that naval involvement is a solution space, in wicked problems terms. The number of attacks globally per year signals that the frequency of the problem is really low which than leads to that piracy is a possible problem and not a probable one (cf. Aggarwal and Bohinc 2011). Nevertheless, piracy has a severe impact on today's supply chain performance and indirectly to their cost profiles (Sullivan 2010; Onuoha 2009).

\section{Theft of goods}

There is a significant problem with the theft of cargo worldwide. It is estimated that theft represents a loss of at least US\$10 billion per year in the United States and US $\$ 30$ billion worldwide (Barth and White 1998; Anderson 2007). These figures are calculated extraordinarily conservatively, since most cargo theft goes unreported and these figures reflect only the value of the items and nothing more (Barth and White 1998). There are predictions that the real figures for cargo theft are either grossly underestimated or overestimated in official reports (Gips 2006). The theft of cargo value for the European Union is estimated to be $€ 8.2$ billion annually, an average value of $€ 6.72$ per trip (EP 2007). Gathering accurate numbers for cargo theft losses is difficult or impossible in many cases, due to limited reporting by the transport industry and the lack of a national law enforcement system requiring reporting and tracking uniformity (ECMT 2001; Ekwall 2010). Even the insurance business has problems separating fraud from real theft, but even if they had accurate numbers they would not share it with the public because of concern about trade secrets and competition. Despite these figures, cargo theft generally has a low priority status in most countries and is often perceived largely as the cost of doing business (EU 2003).

The transport related statistics gives a more coherent picture of the problem with antagonistic threat against transports in the EU. According IRU (2008), the direct cost for an attack is approximately $€ 25000$ per attack, including theft of vehicles, load and the driver's personal belongings. Seventy percent of attacks against road transports occur between 22:00 in the evening and 06:00 in the morning (IRU 2008). According to Saunders (2008) is it possible that "some perpetrators respond to sophisticates transport security measures by increasing their use of unsophisticated and brutal violence against drivers and terminal personnel". Similar development is expressed by EP (2007): The criminal organisations seem to react to the increase security with more aggressive methods.

Cargo theft has the character of both tame and wicked problem as within the different types of cargo theft there are both modus operandi that can be considered as tame problem whiles others as clearly wicked problems (Ekwall 2009a). The small (value vice) thefts have a tamer problem description as they tend to be more predictable both in frequency and time/place occurrence. The thefts which lead to higher (value) losses are a more dynamic nature and lower frequency, which make them wicked. The displacement effect within cargo theft (Ekwall 2009b) is a clear indicator of that there are no silver bullet to solve these problems (Ekwall 2010). This means that the problem description needs to utilize the wicked problem description. 


\section{Analysis}

The recognition that antagonistic threats against supply chain activities is a wicked problem leads to that in research, it is important to place or relate the research questions closer to the specific context. As shown through the wicked problem approach, the answers may contain competing and/or incompatible parts which depend on the perspective or viewpoint at the moment. According to Rittel and Webber (1973), the key to a wicked problem is to understand its context through different solution concepts. A wicked problem is continually evolving and mutating, and the solution is strongly connected with better or worse instead of right or wrong (Ritchey 2008), which is normal in logistics research.

The wicked problem of antagonistic threats against the transport network changes depending on the stakeholder that delivers the judgment and interpretation of the problem. Therefore, the necessary common ground for describing the problem is missing or described differently. According to Lawson (1997), social activity is embedded in material circumstances. This makes a separation of material and nonmaterial structures of the logistics business impossible. As Aastrup and Halldórsson (2008) claim, the perception of social phenomena needs to be included in the analysis. A contextual understanding of the occurrence of antagonistic threats in freight processes is vital. Insights from complexity theory guide the search for a few guiding principles that describe the behaviour of the system (Gault and Jaccaci 1996). To think in terms of complexity means to appreciate the idea that every change affects, in non-linear ways, other parts of the system. Complexity theory gives us a system understanding based on subjectivity and paradoxes instead of objectivity and rationality in interaction between actors (Macbeth 2002).

The complex relationship between transports and antagonistic threats starts with the motivated perpetrator and continues with the logistics functions that relate to the perpetrator and elements of crime. Utilizing Rosenhead's (1996) suggested criteria for wicked problems gives the following result for antagonistic threats against supply chain activities.

Accommodate multiple alternative perspectives The low frequency and sometimes high impact effect from antagonistic threats on supply chain activities leads to that one solution or viewpoint do not provide sufficient understanding of both the cause and the consequences of any antagonistic threats attack. The "black swan" description used by Aggarwal and Bohinc (2011) is a clear indication that these type of problems needs to be understood from more than one angle. Aggarwal and Bohinc (2011) stats that the real black swans are even not forecast able and also linked to great impact on the supply chain. This together with the chain of event leading up to the different antagonistic top events, it is clear that the real danger is that no one really can't foresee the attacks and therefore do the solution need to be built upon several different perspective. Furthermore is it important to understand that each actor or stakeholder in the supply chain has different relationships to antagonistic threats and are therefore affected differently by them.

Function through group interaction and iteration No one does alone control the flow of goods or other linked activities in a supply chain. This means simple that no one is 
alone in a supply chain. Consequently, do these mean that all members in a supply chain are more or less linked to each other and thereby vulnerable for both bullwhip (moving upstream) and the domino effects (moving downstream) in a certain supply chain. In Christopher (2005) defining of the supply chain is the mutual relation and dependencies evident. This means that the supply chain members need to work together, to different extent, in order to handle both the risk and impact from antagonistic threats. In logistics research is the belief that everybody wants to collaborate fairly and for the greater good (Mears-Young and Jackson 1997; Gentry 1996; Lambert et al. 1998b; Yu et al. 2001). This view is not shared of all (Cox et al. 1992; Ekwall and Nilsson 2008). In the world of logistics research is this phenomenon known as misalignments in the supply chain. According to Narayanan and Raman (2004), misalignments in the supply chain are related to hidden actions by partner firms, hidden information, and badly designed incentives. Hence, misalignments occur when different parts of a system are operating to maximise individual performance instead of the system performance. The wickedness of antagonistic threat really need to be addressed holistically, other vice there will always be a soft spot. The current piracy threat at Horn of Africa, and all related problems, is clear evidence that this is a wicked problem.

Generate ownership through transparency Transparency is one of the core elements of supply chain management. Simplistically states does this mean that the supply chain must have transparency in order to work as a chain and not only being several individual organisations doing business together. According Gould et al. (2010) is the lack of transparency in the logistics sector one of the driving forces behind the vulnerabilities in the supply chain. These vulnerabilities refers to the lack weaknesses in the supply chain to actually do something to prevent losses in general (Barnes and Oloruntoba 2005; Wagner and Bode 2006) but also to deter antagonistic threats from attacking the supply chain. The first step to take in this direction is to share information (as in SCM) about losses, threats and preventions methods. Today there is no common understanding about antagonistic threats, not even the frequently more common types like small thefts without the use of violence (Ekwall 2010).

Facilitate a representation of the solution space Following the logic in the previous section, there is no silver bullet (Ekwall 2010; Tatham and Houghton 2011) to solve these types of problems. The dynamics of antagonistic threats means that the threat changes as the countermeasures do. It maybe not be working according the displacement effect (Ekwall 2009b) but the threat changes in response both the countermeasures and other changes in the surrounding world. The changes in threats are evident for piracy, terrorism and also for theft. There are a big difference between what is stolen (or smuggled) and the modus operandi for it. What is governs, like in normal business, of what customer wants whiles the how is more dependent on the existing security and other types of risks for the perpetrators. The how is also more liked to different individual actors in the supply chain whiles the what is more of supply chain common interest. This leads to that the solution needs to be described as a solution space, which more describe different general solutions which differs, one way or another, then they are implemented at any place/link/organisation in the 
supply chain, all according to the current localized antagonistic threat description. This requires full transparency in the supply chain to work.

Focus on relationships between alternatives rather than continuous variables The normative view of logistics as a continuous process (a.k.a., supply chain perspective) needs to be modified when managing antagonistic threats due to that no threat situation are exactly like an earlier threat. There are always some unique features to each threat, even if they are very small. This leads to that alternative strategies are needed at the same time in the same place/link/organisation (Ekwall 2009a). The international aspect of all supply chain activities really needs to be taken into account strategies hindering antagonistic threats from utilizing the vulnerabilities in the supply chains. The key word illegal (in the definition of antagonistic threat used in this paper) is actually not a stable element, due to that what is illegal is stipulated in national laws (sometimes international, but not recognised by all national legal bodies). The result from this is that actors in the supply chain need to focus more on alternatives (strategies, KPI or other variables) than ones normally used in supply chains. The cases with terrorism, piracy and especially smuggling of counterfeited products are evidence for the need for relationships between alternatives.

Concentrate on possibility rather that probability The risks for antagonistic threats have a lower probability than process failures but the consequences for the flow of products may be larger and transmitted through the chain. In extreme cases is it good to label these threats as black swans (Aggarwal and Bohinc 2011). The most extreme supply chain black swan is the threats from terrorism. The new problem of noneconomically driven antagonistic threats toward the transport network requires a different distribution of the total supply chain risks. This does not necessarily lead to a change of risk mitigation strategies, only a different outcome. The fear of noneconomically driven antagonistic threats has caused the creation of different supply chain security programmes. This alone demonstrates that supply chain activities today are getting prepared in order to deal with different wicked problem. One possible problem with the different supply chain security programmes is that they advocates different standardised (to different extent) solutions, where they should more be focusing solution method (or spaces) to really deal with the wickedness of antagonistic threats. This mean that the risk management process should concentre more on possible scenarios then, like in normal cases, the probable scenarios, all in order to find the black swans.

Therefore, is antagonistic threats against supply chain activities a wicked problem and it is essential that to understand the context to understand the problem, even if one antagonistic threat problem may look similar to another.

\section{Conclusion}

The complexity of antagonistic threats against supply chain activities is found both on the threatening side as well as on the presenting side. This leads to the conclusion that, the in logistics normal, problem definition as tame problem do not capture the full complexity and thereby misses the dynamic in the needed problem description. 
Consequently, must antagonistic threats be described and presented as, to different extent, wicked problems. The theoretical implication from this is an argent need for interdisciplinary research approaches. This is according to Stock (1997), nothing new in logistics research as it is normal to use of theories from other scientific fields. These theories derive from areas such as economics, philosophy, organization theory, and as this paper shows even criminology. The interdisciplinary exchange of views, ideas, and theories is needed to develop as an applied science (Klaus et al. 1993). In order to meet the scientific and practical demands from a wicked problem area, as antagonistic threat, is this interdisciplinary exchange of outermost significance in order to first understand the problem and then create countermeasures based on problem description. The examples for terrorism, piracy, smuggling and cargo theft clearly points out the need for mutual (several different stakeholders acting together) problem solving in a solution space, utilizing several different viewpoints simultaneously. This also calls for transparency between these stakeholders in order to focus on relationships between alternatives scenarios while trying to solve possibility rather that probability problems, the so called black swans (Aggarwal and Bohinc 2011).

The economically driven antagonistic threats are subject to the supply and demand forces of the gray market, while non-economically driven antagonistic threats are linked to political/ideological/religious issues. These driving forces, along with such opportunities as the unique combination of object, place, time, method, and security (or lack of), contribute to the risks and uncertainty in supply and transport chains. The characteristics of antagonistic threats against the transport network can be described with a few guiding principles that also describe the behaviour of the system. Therefore, understanding the characteristics of antagonistic threats is based on subjectivity and paradoxes instead of objectivity and rationality in the interaction between actors/elements/stakeholders. This leads to that antagonistic threats against supply chain activities is wicked problems and it is essential that to understand the context to understand the problem, even if one antagonistic threat problem may look similar to another.

The topic needs more attention from both academias' as well as from the supply chain practitioner themselves (Tatham and Houghton 2011). The big difference from "normal" research linked to supply chain activities is that by including the threat into the research frame, the holistic approach requires a wicked problem description instead of the normally used tame problem. This leads to that in order to create new theories and knowledge about antagonistic threat against supply chain activities must logistics research continues to elaborate with theories from other scientific fields (Ekwall 2010). This paper presents a general view point how the wicked problem description will benefit the future research about antagonistic threats against supply chain activities by both utilizing theories from criminology as well as describing the problems contextual surroundings.

\section{References}

Aastrup J, Halldórsson A (2008) Epistelmological role of case studies in logistics: a critical realist perspective. Int J Phys Distrib Logist Manag 38(10):746-763

Abeyratne R (2010) Managing the twenty-first century piracy threat. In: Thomas A (ed) Supply chain security, Vol. 1. ABC-CLIO, Santa Barbara 
Ackoff RL (1974) Redesigning the future: a systems approach to societal problems. Wiley, New York

Aggarwal R, Bohinc J (2011) Black swans and supply chain strategic necessity. J Transp Secur. doi: $10.1007 / \mathrm{s} 12198-011-0080-5$

Anderson B (2007) Securing the supply chain - prevent cargo theft. Security 44(5):56-58

Arlbjörn JS, Halldorsson A (2002) Logistics knowledge creation: reflections on content, context and processes. International journal of physical distribution \& logistics management 32(1):22-40

Badolato EV (2000) Smart moves against cargo theft. Secur Manag 44(7):110-115

Barnes P, Oloruntoba R (2005) Assurance of security in maritime supply chains: conceptual issues of vulnerability and crisis management. J Int Manag 11(4):519-540

Barth S, White MD (1998) Hazardous cargo. World Trade, November 1998, pp. 29

Beck A (2002) Automatic product identification \& shrinkage: scoping the potential. ECR Europe, Brussels

Bodman PM, Maultby C (1997) Crime, punishment and deterrence in Australia - A further empirical investigation. Int J Soc Econ 24(7/8/9):884-901

Bowersox DJ, Closs DJ, Cooper MB (2002) Supply chain logistics management, 2nd edn. McGraw Hill/ Irwin series, Boston

Bruck T, Wickstrom BA (2004) The economic consequences of terror: guest editor's introduction. Eur J Polit Econ 20:293-300

Burke RJ (2005) International terrorism and threats to security: implications for organizations and management. Disast Prev Manag 14(5):639-643

Burnett J (2002) Dangerous waters. Penguin Putnam Inc

Burns V, Peterson KD (2005) Terrorism - A documentary and Reference guide. Greenwood Press

Checkland PB (1999) System thinking, system practice - includes a 30-year retrospective. Wiley, Chichester

Chong YY (2003) How to achieve realistic risk management. Balance sheet 11(4):44-64

Christopher M (2005) Logistics and supply chain management - creating value-adding networks. Prentice Hall, London

Churchman CW (1968) The system approach. Dell publishing, New York

Clarke RV, Cornish D (2003) Opportunities, precipitators and criminal decisions: a reply to Wortley's critique of situational crime prevention. Crime Prevention Studies 16:41-96

Clutterbuck R (1987) Kidnap, hijack and extortion. Basingstoke Macmillan, London

Conklin J (2001) Wicked problems and social complexity. CogNexus Institute, downloaded from cognexus. org/wpf/wickedproblems.pdf.

Cooperstein TM (2009) Letters of marque and reprisal: the constitutional law and practice of privateering. 40 J. Maritime L. \& Comm. 221

Cox A, Ireland P, Lonsdale C, Sanderson J, Watson G (1992) Supply chains, markets and power: mapping buyer and supplier power regimes. Routledge, London

ECMT (2001) Theft of goods and goods vehicles. CEMT/CM (2001)19, Lissabon

Ekwall D, Nilsson F (2008) Using business complexity to handle supply chain risk: dealing with borders of cargo liability. In proceedings of Nofoma 2008, Helsinki

Ekwall D (2009a) Managing the risk for antagonistic threats against the transport network. Division of Logistics and Transportation, Chalmers University of Technology, Göteborg

Ekwall D (2009b) The displacement effect in cargo theft. Int J Phys Distrib Logist Manag 39(1):47-62

Ekwall D (2009c) The risk for detection affects the logistics system setup for cargo smugglers. In proceedings of Nofoma 2009, Jönköping

Ekwall D (2010) On analyzing the official statistics for antagonistic threats against transports in EU: a supply chain risk perspective. J Transp Secur 3(4):213-230

EP - European Parliament's Committee on Transport and Tourism (2007) Organised theft of commercial vehicles and their loads in the European union. European Parliament, Brussels

EU (2003) Freight transport security. Consultation paper, European Commission, Brussels

EU Commission (2008) Public consultation in preparation of a legal proposal to combat counterfeit medicines for human use - key ideas for better protection of patients against the risk of counterfeit medicines, Brussels

Europol (2007) EU Terrorism Situation and Trend Report 2007. The Hague, Netherlands

Europol (2010) EU Terrorism Situation and Trend Report 2010. The Hague, Netherlands

Felson M, Clarke RV (1998) Opportunity makes the thief: practical Theory for crime prevention. Home Office Police and Reducing Crime Unit, London

FIA (2001) Contraband, organized crime and the threat to the transportation and supply chain function. FIA International research 1td

Findlay M (1999) The globalisation of crime. Cambridge University Press. New York 
Fletcher T (2007) Authorised economic operator (AEO) programs: IBM's perspective. World Customs Journal 1(2):61-66

Gammelgaard B (2004) Schools in logistics research? A methodology framework for analysis of the discipline. Int J Phys Distrib Logist Manag 34(6):479-491

Gault S, Jaccaci A (1996) Complexity meets periodicity. Learn Organ 3(2):33-39

Gearson J (2002) The nature of modern terrorism. The political quarterly publishing, pp. 7-24

Gentry J (1996) Carrier involvement in buyer-supplier strategic partnerships. Int J Phys Distrib Logist Manag 26(3):14-25

Gigerenzer G, Reinhard S (2002) Bounded rationality: the adaptive toolbox. MIT Press, Cambridge

Gips M (2006) Cargo security getting some respect. Security management, July 2006, pp.28, ASIS international

Gould JE, Macharis C, Haasis H-D (2010) Emergence of security in supply chain management literature. J Transp Secur 3(4):287-302

Gubi E, Arlbjørn JS, Johansen J (2003) Doctoral dissertations in logistics and supply chain management. A review of Scandinavian contributions from 1990 to 2001. International Journal of Physical Distribution \& Logistics Management 33(10):854-885

Gutiérrez X, Hintsa J, Wieser P, Hameri A-P (2007) Voluntary supply chain security program impact: an empirical study with basc member companies. World Customs Journal 1(2):31-48

Heiner RA (1983) The origin of predictable behaviour. Am Econ Rev 73:560-595

Hellström D (2007) On interactions between Packaging and Logistics - exploring implications of technological developments. Division of Packaging Logistics, Lund University, Lund

Holmes JL (2004) The container security initiative: is container security a global challenge or a supply chain headache. Fleet Equipment, August 1

Horney J, Marshall IH (1992) Risk perceptions among serious offenders: the role crime and punishment. Criminology 30(4):575-594

IACC (2005) White paper, The negative consequences of international intellectual property theft. Washington

IRU (2008) Attacks on drivers of international heavy goods vehicles. International Road Transport Union, Geneva

Jannati F, Salimi M (2011) Modern Sea piracy - Modus operandi and economical and development state backgrounds. School of Engineering, University of Borås, Sweden

Johns T, Hayes R (2003) Behind the fence: buying and selling stolen merchandise. Security journal, Vol. 16, No. 4, Perpetuity Press

Johnston RB, Nedelescu OM (2006) The impact of terrorism on financial markets. J Financ Crime 13(1):725

Klaus P, Henning H, Muller-Steinfahrt U, Stein A (1993) The promise of interdisciplinary research in logistics. In: Masters JM (Ed.), Proceedings of the twenty-second annual transportation and logistics educators conference, pp. 161-87

Klemke (1992), op cit.; Shapland, J. (1995), "Preventing Retail Sector Crimes”. In: Tonry M, Farrington D (Ed.) Building a safer society: strategic approaches to crime prevention, Chicago: The University of Chicago Press

Kroneberg C, Heintze I, Mehlkop G (2010) The interplay of moral norms and instrumental incentives in crime causation. Criminology 48(1):259-294

Ksenia G (2008) Can corruption and economic crime be controlled in developing countries and if so, is it cost-effective? Journal of Financial Crime 15(2):223-233

Lab SP (2000) Crime prevention: approaches, practices and evaluations, 4th edn. Andersson Publishing Co, Cincinnati

Lambert D, Stock J, Ellram L (1998a) Fundamentals of logistics management In: International (ed) McGraw-Hill Higher Education, London

Lambert D, Cooper M, Pagh J (1998b) Supply chain management: implementation issues and research opportunities. Int J Logist Manag 9(2):1-20

Landes DS (1998) The wealth and poverty of nations. W.W. Norton \& Company, New York

Larmour P, Wolanin N (2001) Corruption and anti-corruption. Canberra: Asia Pacific Press

Lawson T (1997) Economics and reality - Economics as social theory. Routledge, London

Lin F, Shaw MJ (1998) Reengineering the order fulfillment process in supply chain networks. The International journal of flexible manufacturing systems 10(3):197-229

Lowe P (2006) Counterfeiting: links to organized crime and terrorist funding. J Financ Crime 13(2):255257

Macbeth D (2002) Emergent strategy in managing cooperative supply chain change. Int J Oper Prod Manag 22(7):728-740 
Madden M (2009) Trading the shield of sovereignty for the scales of justice: a proposal for reform of international sea piracy laws. Univ San Francisco Marit Law J 21(2):139-166

Mainelli M (2008) The wicked problem of good financial markets. J Risk Finance 9(5):502-508

Mankiw NG (1992) Macroeconomics. Worth Publishers, New York

Mankiw NG (1997) Principles of microeconomics. The Dryden Press, Fort Worth Texas

Manunta G (1999) What is security? Security Journal, Vol. 12, No. 3, pp 57-66. Perpetuity Press

Mears-Young B, Jackson M (1997) Integrated logistics — call in the revolutionaries. Omega 25(6):605-618

Napoleoni L (2004) Terror inc. Penguin books ltd

Narayanan VG, Raman A (2004) Aligning incentives in supply chains. Harv Bus Rev 82:94-103

Navarro J, Hayward P, Voros J (2008) How to solve a wicked problem? Furniture foresight case study. Foresight 10(2):11-29

Naylor R (2004) Wages of crime. Cornell University Press, Ithaca

Onuoha FC (2009) Sea piracy and maritime security in the Horn of Africa: the Somali coast and Gulf of Aden in perspective. Afr Secur Stud 18(3):31-44

Pashev KV (2007) Countering cross-border VAT fraud: the Bulgarian experience. Journal of Financial Crime 14(4):490-501

Ritchey T (2008) Wicked problems structuring social messes with morphological analysis. Swedish Morphological Society, downloaded from www.swemorph.com

Rittel HWJ, Webber MM (1973) Dilemmas in a general theory of planning. Pol Sci 4(2):155-169

Rodwell S, Van Eeckhout P, Reid A, Walendowski J (2007) Study: effects of counterfeiting on EU SMEs and a review of various public and private IPR enforcement initiatives and resources. Framework contract B3/ENTR/04/093-FC-Lot 6 Specific agreement nSI2.448309

Rosenhead J (1996) What's the problem? An introduction to problem structuring methods. Interfaces 26 (6):117-131

Ross S, Hannan M (2007) Money laundering regulation and risk-based decision-making. Journal of Money Laundering Control 10(1):106-115

Rystad G (2006) Politiska mord - det yttersta argumentet. Historiska media, Lund, in Swedish

Sampson R, Eck JE, Dunham J (2010) Super controllers and crime prevention: a routine activity explanation of crime prevention success and failure. Security Journal 23(1):37-51

Sarnecki J (2003) Introduktion till kriminologi. Studentlitteratur, Lund, in Swedish

Saunders R (2008) Increasing our vigilance. A presentation at TAPA Q1, Warwick

Sheffi Y (2001) Supply chain management under the threat of international terrorism. Int J Logist Manag 12(2):1-11

Sherman LW, Gartin PR, Buerger ME (1989) Hot spots of predatory crime: routine activities and the criminology of place. Criminology 27(1):27-55

Shultz CJ II, Saporito B (1996) Protecting intellectual property: strategies and recommendations to deter counterfeiting and brand piracy in global markets. Columbia J World Bus 31(1):18-28

Simon HA (1982) Models of bounded rationality. MIT Press, Cambridge

Sjöberg L (2008) Antagonism, trust and perceived risk. Risk Manage 10:32-55. doi:10.1057/palgrave. rm.8250039

Smith A (1776) The wealth of nations. Penguin Books (reprint 1999), New York

Speed M (2003) Reducing employee dishonesty: In search of the right strategy. Secur J 16(2):31-48, Perpetuity Press

Sullivan A (2010) Piracy in the Horn of Africa and its effects on the global supply chain. J Transp Secur 3 (4):231-243

Stock JR (1997) Applying theories from other disciplines to logistics. Int J Phys Distrib Logist Manag 27 (9):515-539

Tarnef B (2006) Combating cargo theft. American Agent \& Broker 78(10)

Tatham P, Houghton L (2011) The wicked problem of humanitarian logistics and disaster relief aid. Journal of Humanitarian Logistics and Supply Chain Management 1(1):15-31

Wagner SM, Bode C (2006) An empirical investigation into supply chain vulnerability. J Purch Supply Manag 12(6):301-312

Wexler MN (2009) Exploring the moral dimension of wicked problems. Int J Sociol Soc Pol 29(9/10):531542

Yu Z, Yan H, Cheng E (2001) Benefits of information sharing with supply chain partnerships. Ind Manag Data Syst 101(3):114-121 